\title{
PENGARUH BODY SHAMING TERHADAP KEPERCAYAAN DIRI MAHASISWA DI UNIVERSITAS ALI SAYYID RAHMATULLAH TULUNGAGUNG
}

\author{
Nella Rahmawati, Muhammad Sholihuddin Zuhdi \\ Prodi Bimbingan Konseling Islam Fakultas Ushuluddin Adab dan Dakwah \\ UIN Ali Sayyid Rahmatullah Tulungagung \\ nellarah96@gmail.com, zuhdi.bk@gmail.com
}

\begin{abstract}
ABSTRAK
Penelitian ini dilatar belakangi oleh banyaknya fenomena perundungan yang dilakukan secara verbal oleh orang-orang yang terjadi di masyarakat. Salah satunya yaitu mengomentari fisik orang lain atau yang disebut dengan body shaming. Saat seseorang memasuki fase usia remaja tentunya akan terjadi perubahan bentuk tubuh, namun terkadang perbuhan bentuk tubuh yang terjadi ini tidak sesuai dengan standart masyarakat dan perubahan ini terbawa hingga dewasa. Penelitian ini bertujuan untuk mengetahui dan memahami tentang pengaruh body shaming terhadap kepercayaan diri mahasiswa. Teknik analisis data mengacu pada femonologi Clark Moustakas. Subjek merupakan mahasiswa yang mengalami body shaming. Penelitian ini menunjukkan bahwa perlakuan body shaming bisa terjadi kepada siapa saja, dan ini membawa pengaruh terhadap kepercayaan diri mahasiswa yang rendah.
\end{abstract}

Kata Kunci: Perundungan Verbal, Body Shaming, Kepercayaan Diri.

\begin{abstract}
ABSTRACK
This research is motivated by the many phenomena of verbal bullying that occur in the community. One of them is commenting on other people's physical or what is called body shaming. When a person enters the phase of adolescence, of course there will be changes in body shape, but sometimes the changes in body shape that occur are not in accordance with community standards and these changes carry over into adulthood. This study aims to determine and understand the effect of body shaming on student selfconfidence. The data analysis technique refers to Clark Moustakas' phenomenology. The subject is a student who experiences body shaming. This research shows that body shaming treatment can happen to anyone, and this has an effect on students' low selfconfidence.
\end{abstract}

Keyword: Verbal Bullying, Body Shaming, Self-Confidence 


\section{PENDAHULUAN}

Era globalisasi ini merupakan perubahan global yang melanda seluruh dunia. Tentunya hal ini membawa dampak yang sangat besar terhadap berbagai aspek kehidupan manusia. Di era ini ilmu pengetahuan dan teknologi mengalami kemajuan yang begitu pesat. Kemajuan teknologi yang sangat pesat ini menghadirkan kemudahan dalam mengakses informasi dari berbagai media, baik melalui televisi, radio, handphone, laptop, dll. Kemudian hal ini membawa dampak pada penyebaran nilai-nilai yang telah dianut masyarakat setempat mengalami pergeseran. Dan pergeseran nilai-nilai yang ada ini tentunya dengan mudah dapat mempengaruhi persepektif dan sikap masyarakat terhadap sesuatu, termasuk standarisasi tubuh ideal terutama bagi remaja.

Saat memasuki usia remaja individu akan mengalami proses perubahan bentuk fisik. Dalam hal ini penampilan fisik telah menjadi nilai utama bagi setiap individu, terutama bagi kaum mahasiswa. Bentuk fisik yang tidak ideal seringkali membuat individu mendapatkan perlakuan body shaming baik dari teman sebaya maupun masyarakat sekitar. Perlakuan body shaming termasuk bullying secara verbal dengan membully bentuk tubuh seseorang (Dolezal, 2015). Body shaming merupakan konsep yang menunjukkan kesadaran diri dan respon negatif terhadap diri sendiri (Chairani, 2018).

Mengomentari bentuk fisik orang lain tanpa disadari sering dilakukan orang-orang, meskipun bukan kontak fisik yang merugikan tetapi body shaming termasuk jenis perundungan secara verbal. Terkadang tanpa disadari individu telah melakukan perundungan secara verbal lewat sebuat bercandaan teman sebaya. Masyarakat menganggap bahwa hal ini bukanlah sesuatu yang salah. Namun bagi korban hal tersebut tentunya membawa dampak yang tidak biasa, hingga berakibat bagi perkembangan dirinya. Individu yang menjadi korban body shaming seringkali menyendiri, pendiam, serta merasa tidak percaya diri.

Perundungan secara verbal ini sudah banyak ditemui dimana-mana, seperti tindakan mengejek, memaki, menggosip, membodohkan, dll. Baik itu dilakukan dalam kontes bercanda maupun serius. Verbal abuse, terjadi ketika orang tua, teman, ataupun orangorang dilingkungan sekitar melontarkan kata-kata yang meremehkan, memojokkan, merendahkan, atau mencap dengan label negatif hingga membuat semua hinaan tersebut mengkristal didalam diri seseorang. Maka dampak yang dialami ialah rasa percaya diri yang dimiliki akan relatif rendah dan juga akan mempengaruhi aspek-aspek kehidupan pribadi maupun sosialnya.

Efek dari perlakuan body shaming sangatlah banyak membawa pengaruh negatif 
terhadap individu. Salah satunya yaitu membuat individu mempunyai tingkat kepercayaan diri yang sangat rendah. Menurut Angelis (dalam Rahayu, 2013:63) berpendapat bahwa kepercayaan diri merupakan sebagai sikap positif sebagai individu yang memampukan dirinya untuk mengembangkan penilaian positif terhadap diri sendiri maupun terhadap lingkungan atau situasi yang dihadapinya. Lutfia (dalam Afiatin \& Martaniah, 2012:2) mengatakan bahwa kepercayaan diri berkembang melalui interaksi individu dengan lingkungannya.

Aspek-aspek kepercayaan diri berdasarkan yang dikemukakan oleh Rosenberg diantaranya keyakinan akan kemampuan diri yaitu individu merasa yakin dan mampu melakukan hal apapun sesuai dengan kemampuan serta berani menghadapi resiko. Optimis, dimana individu selalu berfikir positif terhadap apa yang akan terjadi serta tidak mudah merasa putus asa. Menerima apa adanya, dimana mencerminkan rasa senang sehubungan dengan kenyataan diri sendiri. Mempunyai konsep atau gambaran diri yang baik, dimana individu bisa menilai diri sendiri sebagai sesuatu yang baik.

Bentuk-bentuk body shaming diantaranya Fat Shaming merupakan komentar negatif terhadap orang-orang yang memiliki badan gemuk atau oversize. Skinny / Thin Shaming ini lebih diarahkan kepada perempuan seperti mempermalukan seseorang yang memiliki badan kurus. Rambut Tubuh / Tubuh Berbulu yaitu menghina seseorang yang dianggap memiliki rambut-rambut berlebih di tubuh, seperti di lengan atau kaki. Warna kulit merupakan perlakukan body shaming dengan mengomentari warna kulit, seperti kulit yang telalu pucat atau terlalu gelap. Hal ini tentunya banyak diterima oleh pihak perempuan, yang membawa efek negatif bagi dirinya.

Penelitian ini bertujuan untuk mengetahui bagaiaman pengalaman mahasiswa di UIN Sayyid Ali Rahmatullah Tulungagung yang mengalami body shaming. Metode penelitian yang digunakan dalam penelitian ini yaitu metode kualitatif deskriptif, dengan teknik pengumpulan data yaitu wawancara dan observasi.

\section{METODE PENELITIAN}

Dalam penelitian ini peneliti menggunakan pendekatan kualitatif dengan metode fenomenologi. Penelitian fenomenologi ini mencoba untuk menjelaskan atau mengungkap makna konsep atau fenomena pengalaman yang didasari oleh kesadaran yang terjadi pada beberapa individu. Dimana penelitian ini dilakukan dalam situasi yang alami, sehingga tidak ada batasan dalam memaknai sebuah fenomena yang dikaji. Dalam pandangan fenomenologis ini peneliti berusaha untuk memahami arti suatu peristiwa dan kaitan- 
kaitannya terhadap orang-orang biasa dalam situasi-situasi tertentu. Menurut Creswell (1998:54), pendekatan fenomenologi menunda semua penilaian tentang sikap yang alami sampai ditemukan dasar tertentu. Penundaan ini biasa disebut epoche (jangka waktu).

Subjek dalam penelitian ini dipilih menggunakan random sampling, dimana peneliti memilih subjek berdasarkan kebutuhan yang diperlukan dalam penelitian. Adapun subjek yang akan dipilih yaitu mahasiswa di UIN Sayyid Ali Rahmatullah Tulungagung yang mengalami body shaming.

Pada penelitian ini menggunakan teknik pengumpulan data yang digunakan adalah metode wawancara dan observasi. Wawancara yang digunakan dalam penelitian ini yaitu wawancara mendalam (in-depth interview), merupakan proses memperoleh keterangan dengan cara tanya jawab seraya bertatap muka antara pewawancara dengan infroman. Selain itu juga dilakukan observasi secara bersamaan.

\section{HASIL DAN PEMBAHASAN}

Banyak individu yang mengalami body shaming, hal ini banyak terjadi pada perempuan. Namun juga tidak sedikit yang baru mengetahui istilah body shaming yang memiliki arti sama dengan pembullyan fisik seseorang. Perlakuan body shaming bisa berasal dari mana saja baik dari teman sebaya, tentangga, atau bahkan mereka yang masih memiliki hubungan keluarga sekalipun. Tanpa disadari terkadang perkataan yang mengomentari fisik seseorang terlontar dari mereka itu melukai hati orang yang dikomentari.

Setiap individu memiliki pengalaman body shaming yang berbeda-beda. Seperti dikatai gemuk, pendek, kecil, tiang, jerawatan, item, buluk, ataupun panggilan buruk lainnya. Pada umumnya body shaming merupakan ujaran secara verbal. Namun bagi korban dampak dari perundungan secara verbal sama mematikannya dengan perundungan yang dilakukan secara fisik. Seseorang yang mengalami body shaming cenderung memiliki pemikiran dimana mereka akan lebih bisa diterima jika memenuhi standar masyarakat.

Standar masyarakat yang menganggap bahwa perempuan yang cantik ialah perempuan yang memiliki tubuh tinggi, kulit putih serta tidak berjerawat. Sering kali hal itu membuat seseorang yang mengalami body shaming akan beranggapan jika laki-laki akan lebih tertarik pada perempuan yang cantik juga ideal. Pengalaman body shaming tentunya meninggalkan bekas ingatan serta luka yang berbeda-beda bagi setiap individu. Pada mahasiswa perempuan khususnya, saat adaptasi baru di lingkungan perkampusan 
yang mana merupakan lingkungan baru untuk mereka. Mereka merasa berbeda dengan temannya yang lain sebab tidak bisa memenuhi standar masyarakat membuatnya merasa terintimidasi oleh lingkungan abru.

Perlakuan body shaming memunculkan rasa malu, tertekan, terbebani, hingga putus asa pada korban. Sebagian besar perempuan mendapat perlakuan body shaming langsung dari laki-laki (kekasihnya), dan tentunya ini membawa tekanan yang besar bagi perempuan. Komentar yang diterima setiap individu tentunya sangat beragam mulai dari wajah yang jelek, tubuh yang kurang menarik, hingga tidak cantik. Kondisi ini tentunya membuat korban beranggapan bahwa apa yang dilakukannya selalu tidak lebih baik. Korban body shaming memandang diri mereka sendiri hanyalah sebuah pesan negatif.

Kondisi ini mengacu pada pemikiran dari individu lain yang menilai dirinya sebagai seseorang yang kurang baik maupun rendah. Dia juga beranggapan orang lain melihat dengan rendah dirinya sehingga mengakibatkan menilai diri secara rendah (Gilbert \& Miles, dalam Cahyani, R.R., 2018). Seseorang yang mendapatkan perlakuan body shaming pertama kali tidak bisa melakukan apa-apa. Mereka lebih memilih untuk diam dan memendamnya sendiri, cenderung pasrah dengan yang diterimanya. Hal ini akan memunculkan konsep diri yang tidak baik, dimana mereka akan menyalahkan diri sendiri hingga memunculkan rasa tidak aman dan nyaman bagi individu dalam berpenampilan.

Mahasiswa yang mengalami perlakuan body shaming mendapatkan tekanan dari diri sendiri agar melakukan perubahan guna untuk menghindari perlakuan body shaming kembali. Dimana proses perubahan yang dilakukannya berbeda, tergantung body shaming yang diterimanya. Sebagai contoh salah satu informan yang mengalami body shaming ujaran tentang bentuk tubuhnya yang bulat, dia merasa tidak nyaman setiap kali ada yang mengomentari bentuk tubuhnya. Hingga membuat dia merubah pola hidupnya dengan diet ketat yang dimulai dari memperbaiki pola makan dan juga berolahraga yang rutin. Namun, sebagian ada juga yang tidak melakukan perubahan mereka hanya bisa pasrah atas apa yang diterimanya. Hal ini disebabkan oleh mereka belum siap atas resiko dan efek yang muncul dari perubahan yang dilakukannya.

Dibutuhkan waktu yang tidak sebentar untuk dapat menyikapi serta memunculkan perlawanan terhadap perlakuan body shaming yang dialami oleh seseorang. Mulai dari anggapan bahwa menanggapai komentar dari orang lain tidak ada gunanya ataupun tidak baik membalas ucapan dari orang yang lebih tua dari kita. Perlawanan yang dilakukan oleh informan ini disatu sisi merupakan hal yang positif, dimana mereka mendorong semangat untuk berusaha bangkit serta tidak terpuruk sebab mendapatkan perlakuan body 
shaming. Namun disisi lain juga merupakan hal yang negatif, terkadang disaat informan melakukan pembelaan diri tanpa disadari dia juga melakukan perlakuan body shaming kepada orang lain dengan cara membalikan perkataan mereka.

Individu yang mendapatkan perlakuan body shaming pada akhirnya mengalami suatu proses untuk dapat mengahargai serta mengapresiasi apa adanyan tubuhnya sendiri, atau yang disebut dengan body positivity. Menjadikan pengalaman body shaming sebagai motivasi untuk menghargai tubuh mereka. Meskipun menganggap pengalaman body shaming sebagai motivasi, namun terkadang masih ada hal-hal yang sensitive jika dibahas terkait dengan bentuk badan. Pada akhirnya perlakuan body shaming hingga melakukan body positivity membutuhkan waktu yang tidak sebentar serta suatu proses yang berkelanjutkan.

Kesimpulan penelitian ini terdapat pengaruh body shaming terhadap kepercayaan diri mahasiswa. Para informan yang mengalami perlakuan body shaming merasa malu serta minder dengan temannya yang lain, sebab mereka merasa tidak bisa memenuhi standar masyarakat. Hal ini membuat informan merasa mendapat tekanan yang membuat informan melakukan perubahan terhadap dirinya, agar bisa diterima di masyarakat. Meski sudah melakukan perubahan, namun masih ada hal-hal yang sensitif jika ada yang mengomentari bentuk fisiknya.

\section{KESIMPULAN}

Setelah dilakukan penelitian dengan menggunakan pendekatan fenomenologi terkait pengaruh body shaming terhadap kepercayaan diri mahasiswa di UIN Sayyid Ali Rahmatullahi Tulungagung, seluruh infroman yang berjumlah 4 orang mendapatkan perlakuan body shaming sejak SMA. Perlakuan body shaming yang didapatnya ini berasal dari lingkungan teman sebaya, keluarga, ataupun masyarakat sekitar. Perlakuan body shaming yang dialami oleh informan membuatnya merasa rendah diri, dimana informan tidak memiliki rasa percaya terhadap dirinya.

Seperti halnya tanaman yang tumbuh subur bila mendapat rangsangan yang tepat, seperti cahaya, nutrisi, dan air. Begitupula dengan kepercayaan diri yang tumbuh berkat pesan-pesan positif yang diterimanya. Informan sebagai korban body shaming selalu beranggapan bahwa jika mereka melakukan perubahan tentang body shaming yang diterimanya, mereka akan diterima oleh lingkungannya. Dari hasil penelitian disarankan agar mahasiswa yang mendapatkan perlakuan body shaming diharapkan untuk bisa lebih 
percaya pada dirinya sendiri. Belajar mencintai apa yang ada didalam dirinya, dengan menemukan sisi positif yang ada di dirinya. Untuk individu yang lain belajarlah untuk tidak mengomentari apapun yang ada didalam diri orang lain terutama tentang fisiknya. Berlajar untuk tidak mengomentari walaupun hanya untuk sebuah becandaan, sebab tidak semua orang bisa menerima sebuah becandaan yang dilontarkan sebagah lelucon semata.

\section{DAFTAR PUSTAKA}

Amin. A. (2018). "Hubungan Kepercayaan Diri Dengan Penyesuaian Diri Pada Remaja”. Jurnal Psikologi”. Universitas Yudharta Pasuruan Fakultas: Vol. 5 No.2, hal 79-85 September 2018.

Fauzia, T. F. \& Rahmiaji. L. R. (2019). “Memahami Pengalaman Body Shaming Pada Remaja Perempuan”. Departemen Ilmu Komunikasi Fakultas Ilmu Sosial dan Ilmu Politik, Universitas Diponegoro Semarang.

Hidayat. R., Eka. M. \& Herniyanti. R. (2019). "Hubungan Perlakuan Body Shaming Dengan Citra Diri Mahasiswa". e-ISSN 2655-8106, p-ISSN 2338-2090. Jurnal Keperawatan Jiwa, Univeristas Muhammadiyah Semarang: Vol. 7 No. 1, Hal 7986. Mei 2019.

Perry. M. (2005). "Confidence Booster Pendongkrak Kepercayaan Diri”. Surabaya: Erlangga.

Sakinah. (2018). "Ini Bukan Lelucon”: Body Shaming, Citra Tubuh, Dampak dan Cara Mengatasinya”. Jurnal Emik, Volume 1 Nomor 1, Desember 2018.

Sari, T. I. \& Rosyidah. R. (2020). "Pengaruh Body Shaming Terhadap Kecenderungan Anorexia Nervosa Pada Remaja Perempuan Di Surabaya". Jurnal Personifikasi : Vol. 11 No. 2 November 2020.

Sartika. (2020). "Pengaruh Layanan Konseling Kelompok Terhadap Kepercayaan Diri Siswa Yang Mengalami Body Shaming SMA Negeri 4 Kota Bengkulu”. ISSN 2599-1221 (Cetak) ISSN 2620-5343 (Online), Jurnal Consilia : Volume 3 No 3 2020 : hal 236-243

Taylor. R. (2011). “Kiat-Kiat Pede Untuk Meningkatkan Rasa Percaya Diri”. Jakarta: Gramedia.

Cinara, T. S. (2020). "Ayo Kita Berhenti Untuk Melakukan Body Shaming Mulai Sekarang”. 5 Januari 2017

Widyastuti. R. S. (2015). "Pengaruh Bullying Verbal Terhadap Self-Confidence”. Proposal Penelitian Psikologi, Universitas BINUS 20 September 2015. 